\title{
Airway stents: a retrospective evaluation of indications, results and complications in our 10-year experience
}

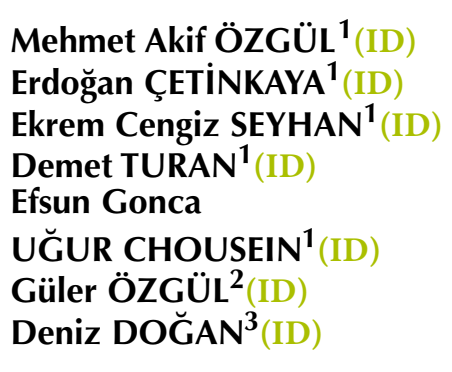

Cite this article as: Özgül MA, Cetinkaya E, Seyhan EC, Turan D, Uğur Chousein EG, Özgül G, et al. The prognostic analysis of the some clinicopathological parameters and gene protein expressions in malignant mesothelioma. Tuberk Toraks 2019;67(4):272-84.

\section{Yazışma Adresi (Address for Correspondence)}

Prof. Dr. Ekrem Cengiz SEYHAN

İstanbul Yedikule Göğüs Hastalıkları ve

Göğüs Cerrahisi Eğitim ve Araştırma Hastanesi, Göğüs Hastalıkları Kliniği,

ISTANBUL - TÜRKIYE

e-mail: drekremcs@yahoo.com

CCopyright 2019 by Tuberculosis and Thorax.

Available on-line at www.tuberktoraks.org.com
${ }^{1}$ Clinic of Chest Diseases, Istanbul Yedikule Chest Diseases and Chest Surgery Training and Research Hospital, Istanbul, Turkey

${ }^{1}$ istanbul Yedikule Gögüs Hastalıkları ve Gögüs Cerrahisi Ĕgitim ve Araştırma Hastanesi, Göğüs Hastalıkları Kliniği, İstanbul, Türkiye

${ }^{2}$ Clinic of Chest Diseases, Istanbul Bagcilar Training and Research Hospital, Istanbul, Turkey

${ }^{2}$ istanbul Bağcılar Ĕ̆itim ve Araştırma Hastanesi, Göğüs Hastalıkları Kliniği, İstanbul, Türkiye

${ }^{3}$ Clinic of Chest Diseases, Gulhane Training and Research Hospital, Ankara, Turkey

${ }^{3}$ Gülhane Ĕgitim ve Araştırma Hastanesi, Göğüs Hastalıkları Kliniği, Ankara, Türkiye

\section{ABSTRACT}

Airway stents: a retrospective evaluation of indications, results and complications in our 10-year experience

Introduction: Tracheobronchial stents (TBS) are the principal modalities in the management of central airway obstruction with intrinsic tracheobronchial pathology and extrinsic airway compression. The aim of the study is to assess the indications, surveillance management, complications, and long-term outcomes of the TBS managed by rigid bronchoscopy (RB) in our 10-year experience.

Materials and Methods: The files of all patients who underwent stenting in two centers from November 2008 to September 2018 were reviewed for background data, type of disease, and indication for the placement of stents, symptoms, treatment, complications and outcome.

Results: 305 patients were stented with 342 TBS. TBS were placed in both malignant $(n=223)$ and benign airway diseases $(n=82)$. The median length of stent stay was 88 (34-280) days in patients with malignancies and 775 (228-2085) days in benign diseases. There was no stent-related mortality. Mucostasis (19\%) and granulation tissue formation (17\%) were the most common stentrelated complications. Benign nature of the disease, tumors metastatic to tracheobronchial tree, lenght of stent stay, and shape of stent were associated with the development of complications.

Conclusion: TBS offer a safe and effective therapy for patients with both benign and malign tracheobronchial pathologies.

Key words: Tracheobronchial stents; stent complication; central airway obstruction 
Özgül MA, Çetinkaya E, Seyhan EC, Turan D, Uğur Chousein EG, Özgül G, et al.

\section{ÖZ}

Hava yolu stentleri: endikasyonların, sonuçların ve komplikasyonların retrospektif olarak değerlendirilmesi; 10 yıllık tecrübemizle

Giriş: Trakeobronşiyal stentler (TBS), santral hava yolu obstrüksiyonlarındaki iç trakeobronşiyal patolojiyi ve dış hava yolu kompresyonunu yönetmek için kullanılan başlıca yöntemdir. Bu çalışmanın amacı 10 yıllık tecrübemiz ile rijid bronkoskopi (RB) ile uygulanan TBS'nin endikasyonlarını, sürveyans yönetimini, komplikasyonlarını ve uzun vadeli sonuçlarını değerlendirmektir.

Materyal ve Metod: Kasım 2008-Eylül 2018 tarihleri arasında iki merkezde TBS yerleştirilmiş olan tüm hastaların dosyaları; arka plan verileri, hastalık tipi ve stentlerin yerleştirilmesi, semptomlar, tedavi, komplikasyonlar ve sonuç endikasyonları açısından incelendi.

Bulgular: Toplam 305 hastaya 342 TBS yerleştirildi. TBS'ler malign $(n=223)$ ve benign hava yolu hastalıkları $(n=82)$ olan hastalara yerleştirildi. Ortanca stent kalış süresi malign hastalığı olanlarda 88 (34-280) gün, benign hastalığı olanlarda 775 (228-2085) gündü. Stent ilişkili mortalite görülmedi. Mukostaz (\% 19) ve granülasyon dokusu oluşumu (\% 17) en sık görülen stent komplikasyonlarıydı. Hastalı̆̆ın benign olması, trakeobronşiyal metastatik tümörler, stent kalış süresi ve kullanılan stentin şekli komplikasyonların gelişimi ile ilişkiliydi.

Sonuç: TBS'ler, benign ve malign trakeobronşiyal patolojisi olan hastalar için güvenli ve etkili bir tedavi sunar.

Anahtar kelimeler: Trakeobronşiyal stent; stent komplikasyonu; santral hava yolu obstrüksiyonu

\section{INTRODUCTION}

Central airway obstruction (CAO) is defined as obstruction of major airways, namely, the trachea and the main bronchi. In adult patients, CAO can occur due to several benign and malignant etiological causes. Patients with significant $\mathrm{CAO}$ often experience dyspnea, respiratory distress, and obstructive pneumonia, and frequently die due to suffocation within hours or days. Although surgical resection with reconstruction is the first-line treatment, many patients with comorbidities are not suitable candidates for surgery (1). For these patients, therapeutic bronchoscopy (dilation, argon plasma coagulation (APC), laser vaporization, cryotherapy, and electrocautery) provides rapid palliation that can be lifesaving and improve quality of life (2). However, none of these therapeutic bronchoscopy techniques provide a remedy for intrinsic airway pathology or extrinsic compression. Airway stenting with tracheobronchial stents (TBS) via rigid bronchoscopy (RB) is a well-established procedure in the management of such conditions (3).

TBS, also known as tracheobronchial prostheses, are tubular devices that are used to treat various benign and malignant CAO's and tracheobronchoesophageal fistulas (TBEF) in order to maintain luminal patency and integrity (4). Several studies have proved the effectivity of stents in palliative and curative treatment of CAO and TEF; in fact, they lead to a significant improvement not only in symptoms and lung function but also in quality of life and survival, if stenting is done on time (5).

TBS are made of different types of materials and have advantages and disadvantages according to their structure. TBS have complications such as migration granulation tissue formation, impaired mucociliary clearance, recurrent lumen obstruction of the stent, and increased bacterial colonization (6-8). Although stenting with TBS is becoming a very popular therapeutic option for patients with tracheobronchial disorders, most interventional pulmonologists do not have well-defined follow-up schedules or protocols (9). This study represents our institutional experience of various airway stenting and follow-up period for the management of obstructive benign and malignant tracheobronchial disorders.

\section{MATERIALS and METHODS}

The study enrolled from November 2008 to September 2018 in the interventional pulmonology department of Yedikule Chest Disease and Thoracic Surgery Research and Training Hospital. Databases of our center was searched for records of subjects who underwent stenting with TBS. Before TBS placement, informed consent was obtained from patients and/or parents outlining all potential risks (including airway perforation, infection, dislocation, obstruction, respiratory distress, and death). In studies with a retrospective analysis of standard diagnostic data, no ethical approval is needed in Turkey. Scientific Study Committee of our hospital reviewed and approved the database.

The following information was retrieved from the database: Demographic details, clinical diagnosis, bronchoscopic findings (site of lesion, type of obstruction, and stenosis percentage), treatment modalities (surgery, chemotherapy, radiotherapy), indication for stenting, features of stents, success of stenting, proce- 
dure and stent-related complications, duration of follow-up, and survival time. Before the airway stenting, each patient underwent a standard pre-operative and clinical assessment, including physical examination, performance status [the American Society of Anesthesiologists (ASA)], routine laboratory tests, computed tomography (CT) of the chest and flexible bronchoscopy (FB) under local anaesthesia to evaluate airway anatomy and plan the optimal approach for treatment. Multiple therapeutic modalities were used including mechanical debulking and dilatation with the rigid broncoscopes (RB), balloon dilatation, Neodymium-Doped Yttrium Aluminium Garnet $(\mathrm{Nd}$ : YAG) laser photocoagulation, and argon plasma coagulation (APC). The equipment used included the Dumon Series II RB (Efer Endoscopy, La Ciotat, Paris, France) with an optical system, stent introducer, and forceps, and FB (model 1T-180; Olympus America Inc, Melville, N.Y, USA). APC ( $40 \mathrm{~W}$, blended mode/ continuous flow) was applied using an instrument by ERBE Elektromedizin GmbH (Tubingen, Germany). A diode laser operating at a wavelength of $980 \mathrm{~nm}$ with 4 to $25 \mathrm{~W}$ in pulsed mode (Biolitec Cerals D25; Jena, Germany) was used for the endoluminal treatment. Cryotherapy was performed using the ERBOKRYO system (Elektromedizin $\mathrm{GmbH}$, Tubingen, Germany). TBS used in the procedures could be classified in 3 groups according to material there are made of as follows; silicon stents (SS), metallic stents (MS), and hybrid stents (HS) and in 5 groups according to the shapes as; Y-shaped, straight, J-shaped, Oki, and stenotic stents.

The first phase of the procedure started with an evaluation of the airway and followed by treatment of endoluminal disease with any of the following techniques; mechanical debulking, laser ablation, APC, cryotherapy, and balloon dilatation. The stenotic segment of the airway was mechanically dilated directly with increasing sizes of the RB rotating it around itself. If the stenotic segment could not be treated with the RB then a rapid balloon bronchoplasty was performed. Endobronchial tumors were managed primarily by the Nd: YAG laser and/or APC than this procedure was followed by mechanical débridement and the retrieval of the debrided mass with the help of biopsy forceps and cryo-probe. The next step was the measurement of the diameter and length of the disease-affected trachea and main bronchi. The trachea was intubated with a larger lumen $\mathrm{RB}$ (internal diameter, $14 \mathrm{~mm}$ ). The stent was loaded into a spesific designed introducer and deployed using the applicator through the RB utilizing either "pushing" or the "pulling" technique.

FB was performed 24 hours after stenting. Hypoxemia (desaturation below $90 \%$ for more than $1 \mathrm{~min}$ ), and respiratory insufficiency requiring mechanical ventilation (MV), arrhythmia, hemorrhages, and death within 24 hours after the procedure, were considered to be acute complications. During every visit, FB under local anesthesia was also performed, to evaluate stent position and potential chronic complications such as migration, granulation tissue formation at the edges of the stent, stent fracture and secretion plugs. The primary outcomes of the present study were defined as the assessment of technical and clinical success of TBS, and the complications of the stenting. Technical success was defined as successful placement in the appropriate site in one bronchoscopic session. Clinical success was considered in terms of clinical improvement when the patient was weaned off mechanical ventilation or a dramatic improvement in respiratory symptoms in the subsequent period after the procedure.

\section{Statistical Analysis}

Statistical analyses of the data obtained in the study were made using R software. Variables were given as the mean or median with a standard deviation value. Student's t-test was used to compare means and Mann-Whitney $U$ test was used to compare medians. Frequencies were compared with Chi-square and Fisher's Exact test. Spearman and Pearson correlation tests were used for correlation analysis. The date of stenting was considered as zero-day, last check date or date of death was considered as last day on survival analysis. Kaplan-Meier survival analysis was performed for univariate survival analysis. Log-rank or Cox tests were used for comparison of survival rates of groups. Cut-off values for continuous variables were identified using receiver operating characteristic (ROC) analysis ( $\mathrm{R}$ Software). Variables that were associated with survival at $p<0.10$ in univariate analysis were included in multivariate analysis. The Cox relative risks model was used for multivariate analysis of these factors that were likely to affect the survival. Forward stepwise analysis method was preferred to show that the variable independently affects the survival. A p-value of less than 0.05 was considered to be significant. 


\section{RESULTS}

\section{Clinical Features of the Study Population}

From November 2008 to September 2018, 305 patients underwent stenting with 342 TBS (a median of one stent per patient; range 1-4) in two hospitals. All patients were symptomatic; principal symptoms were dyspnea in $88 \%$, stridor in $33 \%$, hemoptysis in $22 \%$, and respiratory failure in $14 \%$. The mean ASA patient score prior to intervention was $2.94 \pm 0.64$ (range 1-4). The majority of patients (73\%) had an obstruction ratio of airways greater than $75 \%$. Malignancy $(223,73 \%)$ was the most common cause of stenting. The most frequent malignancy responsible for stenting was non-small cell lung cancer (NSCLC) (Table 1). Of the 223 patients with malignant disease (MD), 205 (92\%) had undergone previous radiation, chemotherapy, or both. Twenty-nine patients $(23 \%)$ had a history of previous surgery. Leading benign indication for airway stenting (82 patients) was the post-intubation tracheal stenosis (PITS) (40, 48\%) (Table 1).

\section{Procedure of Stenting}

A total of 342 TBS were placed, and the stent was successfully deployed in all cases. The indications for TBS placement were CAO $(82 \%)$ and TBEF $(5 \%)$, TBM $(13 \%)$. The majority of patients $(90 \%)$ required only one stent procedure, but a significant number of patients required two stent procedures $(7 \%), 3$ stent procedures $(2 \%)$, and 4 stent procedures $(1 \%)$ to maintain stent patency and airway palliation. The placement of TBS resulted in immediate relief of symptoms in $95.2 \%(289 / 305)$ subjects at once. Seventy-seven percent of the patients had additional procedures (Table 2).

\section{Analysis of Stent Complications}

Acute complications $(<24 \mathrm{~h})$ were recorded in 30 patients $(10 \%)$. No severe hemorrhage was observed (Table 3). Chronic complications ( $>24 \mathrm{~h}$ ) of the stents occurred in 98 of 342 procedures (32\%). The most common chronic complication was mucostasis of the stent (Table 3). Complications in patients with malignant conditions presented earlier than those in patients with benign conditions $(p=0.04)$. The complication rates following stenting were as follows, stent migration ( $15 \%$ vs. $6 \% ; p=0.01)$, granulation tissue formation (23\% vs. $14 \% ; \mathrm{p}<0.05)$, and mucostasis $(26 \%$ vs. $11 \%$; $p=0.02)$ and were signifi-
Table 1. Demographic and clinical details of the study population $(n=305)$

\begin{tabular}{|c|c|}
\hline Variables & Value \\
\hline Age, years ${ }^{\mathrm{a}}$ & $57.7 \pm 11.5$ \\
\hline Gender (male), n (\%) & $218(71)$ \\
\hline \multicolumn{2}{|l|}{ Etiology } \\
\hline Benign, n (\%) & $82(26)$ \\
\hline Anastomotic (PA/PT) & $8(10)$ \\
\hline PITS & $40(48)$ \\
\hline PTTS & $15(18)$ \\
\hline TBM & $9(10)$ \\
\hline TBEF & $7(8)$ \\
\hline Vascular compression & $3(4)$ \\
\hline Idiopathic & $3(4)$ \\
\hline Malignant, n (\%) & $223(74)$ \\
\hline Primary tracheobronchial or lung tumors & $186(83)$ \\
\hline Non-small cell lung cancer & $94(42)$ \\
\hline Small cell lung cancer & $70(31)$ \\
\hline Bronchial carcinoid & $8(4)$ \\
\hline Malign mesenchymal tumor & $6(3)$ \\
\hline Adenoid cystic carcinoma & $3(1)$ \\
\hline Others + & $5(2)$ \\
\hline Tumors metastatic to tracheobronchial & $37(17)$ \\
\hline Eosephagus & $12(5)$ \\
\hline Thyroid & $6(3)$ \\
\hline Lymphoma & $5(2)$ \\
\hline Colorectal & $4(2)$ \\
\hline Renal cell & $3(1)$ \\
\hline Ovarian & $3(1)$ \\
\hline Others ++ & $4(2)$ \\
\hline \multicolumn{2}{|l|}{ Site of lesion } \\
\hline Trachea & $122(40)$ \\
\hline Left main bronchus & $23(8)$ \\
\hline Right main bronchus & $32(11)$ \\
\hline Trachea and each or both bronchi & $128(41)$ \\
\hline \multicolumn{2}{|l|}{ Type of stenosis } \\
\hline Intrinsic obstruction & $116(38)$ \\
\hline Extrinsic obstruction & $76(25)$ \\
\hline Complex & $113(37)$ \\
\hline
\end{tabular}

a Results given as mean \pm SD; $n$ : Number of cases, PITS: Post-intubation tracheal stenosis, PTTS: Post-tracheostomy tracheal stenosis, TBM: Tracheobronchomalacia, TBEF: Tracheobronchoesophageal fistula, PA: Post-anastomotic, PT: Post-transplantation, Others+; carcinoma in situ (2), low grade neuroendocrine tumor (2), malign epithelial tumors (1); Others++; malignant melanoma (1), endometrium (1), parotis (1), breast (1), larynx (1) cancer.

cantly different in patients with benign conditions and those with malignant conditions (Table 3).

Complications were directly correlated with tumors metastatic to tracheobronchial $(r=0.16, p=0.004)$, follow-up days after airway stenting $(r=0.4, p<$ $0.001)$, stent shape $(r=0.21, p<0.01)$, and inversely 
Evaluation of airway stents: 10 years of experience

Table 2. General characteristics of cases with airway stenting

\begin{tabular}{|c|c|c|c|c|}
\hline & $\begin{array}{l}\text { All patients } \\
(n=305)\end{array}$ & $\begin{array}{l}\text { Patients with BD } \\
(n=82)\end{array}$ & $\begin{array}{l}\text { Patients with MD } \\
\qquad(n=223)\end{array}$ & $\mathbf{p}$ \\
\hline Ages, years ${ }^{\mathrm{a}}$ & $57.7 \pm 11$ & $56.3 \pm 14$ & $57.9 \pm 10$ & NS \\
\hline Gender (male), n (\%) & $218(71)$ & $45(54)$ & $173(77)$ & $<0.001$ \\
\hline Comorbidities, n (\%) & $76(25)$ & $32(39)$ & $44(19)$ & $<0.001$ \\
\hline Diabetes mellitus & $28(9)$ & $14(17)$ & $14(6)$ & \\
\hline Cardiovascular disease & $36(11)$ & $26(31)$ & $10(9)$ & \\
\hline Cerebrovascular disease & $19(6)$ & $10(12)$ & $9(4)$ & \\
\hline Pulmonary disease & $21(7)$ & $9(10)$ & $12(5)$ & \\
\hline Others ${ }^{b}$ & $11(4)$ & $3(4)$ & $8(3)$ & \\
\hline Stent Indication, n (\%) & & & & NS \\
\hline $\mathrm{CAO}$ & $251(82)$ & $64(78)$ & $187(83)$ & \\
\hline TEF & $17(5)$ & $6(7)$ & $11(6)$ & \\
\hline TBM & $37(13)$ & $12(15)$ & $25(11)$ & \\
\hline \multicolumn{5}{|l|}{ Stent location; n (\%) } \\
\hline Trachea & $103(33)$ & $45(54)$ & $58(26)$ & $<0.01$ \\
\hline Left main bronchus & $11(4)$ & $2(3)$ & $9(4)$ & NS \\
\hline Right main bronchus & $29(10)$ & $7(9)$ & $22(9)$ & NS \\
\hline Trachea and bronchi & $162(53)$ & $15(18)$ & $147(65)$ & $<0.001$ \\
\hline Stent shape, n (\%) & 342 & 98 & 244 & \\
\hline Y-shaped stent & $189(55)$ & $22(22)$ & $167(68)$ & $<0.001$ \\
\hline Straight stent & $73(21)$ & $7(7)$ & $66(27)$ & $<0.001$ \\
\hline Stenotic stent & $64(18)$ & $64(65)$ & - & NA \\
\hline Oki stent & $9(3)$ & $8(10)$ & $1(1)$ & $<0.001$ \\
\hline J stent & $7(2)$ & - & $7(2.3)$ & NA \\
\hline Stent type, n (\%) & 342 & 98 & 244 & \\
\hline Silicon stent & $292(85)$ & $93(94)$ & $219(9)$ & $<0.001$ \\
\hline Metallic stent & $46(13)$ & $6(6)$ & $21(8)$ & NS \\
\hline Hybrid stents & $4(1)$ & - & $4(2)$ & NA \\
\hline $\mathrm{AD}, \mathrm{n}(\%)$ & $237(77)$ & $64(78)$ & $173(77)$ & NS \\
\hline APC & 118 & 8 & 110 & \\
\hline Laser & 37 & 2 & 35 & \\
\hline Cryo & 123 & 11 & 112 & \\
\hline $\mathrm{MD}$ & 95 & 61 & 34 & \\
\hline Ballon & 39 & 34 & 4 & \\
\hline
\end{tabular}

correlated with malign diseases $(r=-0.15, p=0.007)$ (Table 4). While granulation tissue development was more frequent in tumors metastatic to tracheobronchial $(p<0.001), M S(p<0.05)$, prior treatment (nonKT and non-RT) $(\mathrm{p}<0.01)$, and additional processing $(p<0.01)$, migration was observed more frequently in benign diseases $(p<0.05)$ and with straight stents $(p<$ 0.001) (Table 4). Univariate analysis showed stent complications were most closely associated with ASA score $(p<0.01)$, presence of benign disease $(p=$ $0.008)$, presence of extrathoracic origin $(p=0.006)$, stent shape $(p<0.01)$, additional processing $(p=$ $0.004)$, and length of follow-up period ( $p<0.001)$. In the multivariate analysis, patients with the presence of stent complications were only significantly more likely to the length of the follow-up period $(p=0.003)$ (Table 5).

\section{Outcomes and Follow-Up}

After airway interventions 298 of 305 patients (95\%) noted a significant improvement in their symptoms. There was no procedure-related mortality. The mean 
Özgül MA, Çetinkaya E, Seyhan EC, Turan D, Uğur Chousein EG, Özgül G, et al.

Table 3. Complications and follow-up results of cases with airway stenting

\begin{tabular}{|c|c|c|c|c|}
\hline & $\begin{array}{l}\text { All patients } \\
(n=305)\end{array}$ & $\begin{array}{l}\text { Patients with BD } \\
\qquad(\mathrm{n}=82)\end{array}$ & $\begin{array}{l}\text { Patients with MD } \\
\qquad(n=223)\end{array}$ & p \\
\hline Acute complications, $\mathrm{n}(\%)$ & $30(10)$ & $6(7)$ & $24(10)$ & NS \\
\hline Respiratory distress needing MV & $13(4)$ & $2(2)$ & $11(5)$ & NS \\
\hline Minimal-moderate bleeding & $10(3)$ & - & $10(4)$ & NA \\
\hline Atrial fibrillation & $3(1)$ & $2(2)$ & $1(1)$ & NS \\
\hline Trauma to teeth & $4(1)$ & $2(2)$ & $2(1)$ & NS \\
\hline Excessive bleeding & - & - & - & NA \\
\hline Procedure-related death & - & - & - & NA \\
\hline Chronic complications, n (\%) & $98(32)$ & $36(43)$ & $62(27)$ & $<0.05$ \\
\hline Mucostasis & $58(19)$ & $22(26)$ & $26(11)$ & 0.02 \\
\hline Granulation & $52(17)$ & $19(23)$ & $33(14)$ & $<0.05$ \\
\hline Tumor regrowth & $21(7)$ & - & $21(10)$ & NA \\
\hline Stent migration & $27(9)$ & $13(15)$ & $14(6)$ & 0.01 \\
\hline Breakage & $2(0.5)$ & - & $2(1)$ & NA \\
\hline \multicolumn{5}{|l|}{ Treatment of stent complications } \\
\hline Aspiration of secretion & $52(15)$ & $15(18)$ & $37(16)$ & NS \\
\hline AD (Cryo, APC, MD) & $62(18)$ & $17(20)$ & $45(20)$ & NS \\
\hline Stent removel & $34(10)$ & $21(25)$ & $13(6)$ & $<0.01$ \\
\hline Stent replacement & $37(11)$ & $27(32)$ & $10(4)$ & $<0.001$ \\
\hline Time of complication (day) $)^{\mathrm{a}}$ & $22(7-80)$ & $8(1-15)$ & $45(12-145)$ & 0.04 \\
\hline Follow-up after TMS (mounth) ${ }^{\mathrm{a}}$ & $4.8(1-21)$ & $25(7-69)$ & $2.9(1-9.3)$ & $<0.001$ \\
\hline Mortality ratios, n (\%) & $229(75)$ & $32(39)$ & $197(88)$ & $<0.001$ \\
\hline
\end{tabular}

follow-up duration was 5 (2-20) months. The overall 5 -year survival rate of the patients was calculated as $21 \%$. The 5 -year survival rate was $58 \%$ for patients with benign diseases and $7 \%$ for patients with malign diseases $(p<0.001)$ (Figure 1).

Factors significantly affecting survival in malign diseases using the univariate analysis were type of malignancy $(p<0.012)$, degree of airway obstruction $(p<0.1)$, stent shape $(p=0.051)$, and treatment modality $(p=0.04)$. Multivariate analysis showed that the type of malignancy were independent predictors of survival (Table 6, Figure 2). In benign diseases, factors that were found to affect the survival rate on the univariate analysis $(p<0.1)$ (age, the type of underlying benign disease, degree of airway obstruction, and presence of comorbidities) were also used in multivariate analysis of the factors that may affect the survival rate. The analysis showed that age was independently prognostic factors (Table 7 , Figure 3).

\section{DISCUSSION}

Airway stenting is an appealing mini-invasive palliative treatment option for patients with tracheobronchial disorders, who are not surgical candidates. Recent technological advances have increased the popularity of TBS with interventional pulmonologists and chest physicians, particularly because stenting is effective for both extraluminal and intraluminal lesions and promptly relieves acute airway obstruction-related disorders. We evaluated the indications-complications and follow-up period of the stents we applied in past 10-years in this retrospective study and discussed them in the context of the recent literature. Technical success was achieved in $100 \%$ of patients and clinical success in $76 \%$. There was no stent-related mortality. The results of our study suggest that placement of TBS is a safe and effective treatment option in the management of benign and malignant disorders.

TBS are made of silicone, metallic or a combination of both (hybrid stents). Most stents are available in 


\section{Table 4. Correlation coefficients between demographic variables and stent complications}

\begin{tabular}{|c|c|c|}
\hline \multicolumn{2}{|l|}{ Variable } & TBS complication \\
\hline & $r$ coefficient & $\mathbf{p}$ \\
\hline Malign diseases & -0.15 & 0.007 \\
\hline Type of stenosis & -0.01 & NS \\
\hline Tumors metastatic to tracheobronchial & 0.16 & 0.004 \\
\hline Follow-up days after stenting & 0.4 & $<0.001$ \\
\hline Treatment modality & 0.1 & NS \\
\hline Age, years & 0.01 & NS \\
\hline Presence of comorbidities & 0.02 & NS \\
\hline Stent shape (SS) & 0.14 & 0.01 \\
\hline Type of stent & 0.04 & NS \\
\hline \multirow[t]{3}{*}{$A D$} & 0.02 & NS \\
\hline & \multicolumn{2}{|c|}{ Migration } \\
\hline & r coefficient & $\mathbf{p}$ \\
\hline Malign diseases & -0.14 & 0.009 \\
\hline Type of stenosis & -0.05 & NS \\
\hline Tumors metastatic to tracheobronchial & 0.07 & NS \\
\hline Follow-up days after stenting & 0.2 & $<0.001$ \\
\hline Treatment modality & 0.1 & NS \\
\hline Stent shape $(Y-S)$ & -0.25 & 0.001 \\
\hline \multirow[t]{3}{*}{ Type of stent } & 0.06 & NS \\
\hline & \multicolumn{2}{|c|}{ Granulations } \\
\hline & r coefficient & $\mathbf{p}$ \\
\hline Malign diseases & -0.09 & NS \\
\hline Type of stenosis & -0.01 & NS \\
\hline Tumors metastatic to tracheobronchial & 0.16 & 0.04 \\
\hline Follow-up days after stenting & 0.3 & $<0.001$ \\
\hline Treatment modality (KT and RT) & -0.13 & 0.01 \\
\hline Stent shape & 0.03 & NS \\
\hline \multirow[t]{3}{*}{ Type of stent (MS) } & 0.12 & $<0.05$ \\
\hline & \multicolumn{2}{|c|}{ Mucostasis } \\
\hline & $r$ coefficient & $\mathbf{p}$ \\
\hline Malign diseases & -0.18 & 0.001 \\
\hline Type of stenosis & -0.06 & NS \\
\hline Tumors metastatic to tracheobronchial & 0.03 & NS \\
\hline Follow-up days after stenting & 0.2 & $<0.01$ \\
\hline Treatment modality & 0.04 & NS \\
\hline Stent shape (SS) & 0.18 & 0.02 \\
\hline Type of stent & 0.08 & NS \\
\hline
\end{tabular}

various shapes (straight, stenotic, Oki, Y-shaped, J-shaped), diameters, and lengths (10). The main indication for airway stenting is to reduce the symptoms associated with airway obstruction caused by benign or malignant diseases in which medical, surgical, or endoscopic treatments are not sufficient. In both intrinsic and extrinsic airway obstructions, TBS can be used to provide airway patency. In addition, patients with degenerative expiratory central airway collapse (tracheobronchomalacia or selected dynamic airway collapse disease), postsurgery/transplantation anastomotic strictures or patients with TBEF should benefit from stenting $(4,11)$. In our retrospective study, there were numerous diversity of indica- 
Özgül MA, Çetinkaya E, Seyhan EC, Turan D, Uğur Chousein EG, Özgül G, et al.

Table 5. Univariate and multivariate analysis for the presence of any stent-related complications among patients

\begin{tabular}{|c|c|c|}
\hline Variable & $\begin{array}{c}\text { Univariate analysis } \\
\text { p-value } \\
\text { OR }(95 \% \mathrm{Cl})\end{array}$ & $\begin{array}{c}\text { Multivariate analysis } \\
\text { p-value } \\
\text { OR }(95 \% \mathrm{CI})\end{array}$ \\
\hline Age, years & $0.7(0.5-0.11)$ & \\
\hline Male, gender & $0.2(0.09-0.4)$ & \\
\hline ASA score & $0.01(0.001-0.12)$ & $0.09(-0.22-0.1)$ \\
\hline Presence of comorbidities & $0.66(0.61-0.68)$ & \\
\hline Presence of benign disease & $0.008(0.006-0.011)$ & $0.63(-0.4-0.25)$ \\
\hline Tumors metastatic to tracheobronchial tree & $0.006(0.004-0.02)$ & $0.07(-0.11-0.45)$ \\
\hline Type of stenosis & $0.47(0.45-0.48)$ & \\
\hline Stent shape & $0.005(0.003-0.07)$ & $0.7(-0.11-0.08)$ \\
\hline Type of stent & $0.7(0.6-0.8)$ & \\
\hline Treatment modality & $0.2(0.1-0.3)$ & \\
\hline Additional procedure & $0.05(0.03-0.07)$ & $0.08(-0.22-0.37)$ \\
\hline Percentage of lumen obstruction & $0.6(0.6-0.8)$ & \\
\hline Follow-up period & $0.001(0.001-0.01)$ & $0.003(0.005-0.02)$ \\
\hline
\end{tabular}

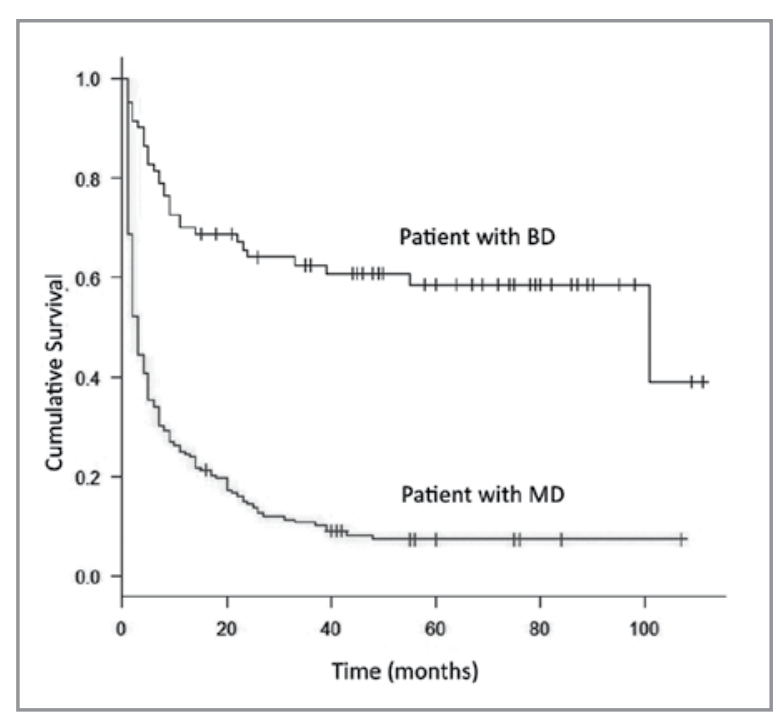

Figure 1. Overall survival of patients after interventional bronchoscopy (MD: Malign diseases, BD: Benign diseases, $\mathrm{p}<0.001$ by log-rank test).

tions for stenting and central airway obstructions (CAO) that were the highest, consistent with the literature. In addition, our study showed that all the patients had symptomatic relief after stenting.

The majority of TBS indications are CAO due to malignant airway tumors. These patients branded with a poor prognosis and should not benefit from surgery with curative intent; however, they will require procedures for palliation with the hope of being provided with an improved quality of life (2). TBS does not treat the tumor; so, the objective of an airway stent is either entirely palliation or treatment and prevention of symptoms of CAO to give an opportunity to those patients to receive systemic therapy (12). In patients with malignancies, the most common indication for TBS placement is bronchogenic carcinoma, which can present as extraluminal compression with or without an intraluminal lesion. Approximately $30 \%$ of patients with bronchogenic carcinoma develop CAO and may require airway stents as part of their management (13). Metastases from both intrathoracic organs such as malignant lymphomas, esophageal tumors, tumors of larynx or thyroid, and extrathoracic organs can also invade the central airways in addition to primary lung malignancies (11). Primary lung cancers were the most common indication for stenting in this study. And metastasis from extrathoracic organs including lymphoma, tumors of the larynx was also seen.

Indications for stenting in benign tracheal stenosis (BTS), include long tracheal strictures, stenosis due to inflammatory diseases, post lung transplantation strictures, tracheobronchomalacia, postintubation tracheal stenosis (PITS) and post tracheostomy tracheal stenosis (PTTS). The treatment algorithm of BTS is well defined and surgery is considered as the first treatment of choice. When surgery is not possible, 
Table 6. Characteristics of the study population affecting survival after interventional bronchoscopic procedures for malignant diseases

\begin{tabular}{|c|c|c|c|c|c|c|}
\hline \multirow[b]{2}{*}{ Characteristics } & \multicolumn{4}{|c|}{ Survival } & \multicolumn{2}{|r|}{$\mathbf{p}$} \\
\hline & $\begin{array}{l}\text { Mean months } \\
(\% 95 \mathrm{Cl})\end{array}$ & $\begin{array}{c}3 \text { months } \\
(\%)\end{array}$ & $\begin{array}{c}6 \text { months } \\
(\%)\end{array}$ & $\begin{array}{c}12 \text { months } \\
(\%)\end{array}$ & Univariate & Multivariate \\
\hline Type of underlying malignancy & & & & & 0.012 & $0.04(0.01-1.2)$ \\
\hline Non-small cell lung cancer & $3(1-9)$ & 36 & 24 & 19 & & \\
\hline Small cell lung cancer & $1(1-5)$ & 23 & 7 & - & & \\
\hline Tumors metastatic to TBT & $2(1-16)$ & 49 & 37 & 27 & & \\
\hline Site of the lesion & & & & & 0.32 & \\
\hline Trachea & $2.5(1-9.5)$ & 36 & 27 & 19 & & \\
\hline Right main bronchus & $2(1-16)$ & 34 & 19 & 17 & & \\
\hline Left main bronchus & $3(1-9)$ & 40 & 31 & 22 & & \\
\hline Trachea + right + left main bronchus & $3(1-9)$ & 53 & 32 & 20 & & \\
\hline Degree of airway obstruction (\%) ${ }^{\mathrm{a}}$ & & & & & 0.1 & $0.9(0.8-1.1)$ \\
\hline Grade $1(<50 \%)$ & $3(1-8.5)$ & 69 & 53 & 32 & & \\
\hline Grade 2 (50\%-74\%) & $3(1-11.7)$ & 65 & 39 & 21 & & \\
\hline Grade 3 (75\%-89\%) & $2.4(1-17)$ & 40 & 33 & 22 & & \\
\hline Grade 4 (90\%-100\%) & $2(1-7)$ & 40 & 25 & 15 & & \\
\hline Type of lesion & & & & & 0.4 & \\
\hline Intrinsic obstruction & $3(1-11)$ & 47 & 32 & 23 & & \\
\hline Extrinsic obstruction & $2(1-13)$ & 40 & 32 & 26 & & \\
\hline Complex & $3(1-8)$ & 43 & 31 & 16 & & \\
\hline Treatment modality & & & & & 0.04 & $0.63(0.6-2.3)$ \\
\hline Surgery & $6.5(1.25-26)$ & 68 & 50 & 42 & & \\
\hline $\mathrm{CT}$ & $2(1-10)$ & 44 & 34 & 24 & & \\
\hline RT & $9.5(2-14)$ & 58 & 45 & 23 & & \\
\hline $\mathrm{CT}$ and RT & $12(2-33)$ & 67 & 43 & 27 & & \\
\hline Sytent type & & & & & 0.69 & \\
\hline SS & $3(1-9.25)$ & 46 & 34 & 23 & & \\
\hline MS & $2(1-6.6)$ & 35 & 29 & 15 & & \\
\hline $\mathrm{HS}$ & $1.5(1-11)$ & 50 & 25 & - & & \\
\hline Stent shape & & & & & 0.051 & $0.3(0.2-11.6)$ \\
\hline Y-shaped stent & $3(1-8)$ & 42 & 29 & 20 & & \\
\hline Straight stent & $3(1-16)$ & 51 & 22 & 49 & & \\
\hline Oki stent & $8(1.7-51)$ & 55 & 45 & - & & \\
\hline J stent & $9(2-43)$ & 66 & 33 & - & & \\
\hline
\end{tabular}

mechanical dilatation is usually proposed and stents are placed only when dilatation fails to offer an acceptable result (14). PITS and PTTS compose the majority causes of BTS (15). In these cases, stents are often considered as better options, essentially because of their retrievable character. Several representative studies of clinical experience with TBS in BTS have been reported (16-18). All patients had immediate symptomatic relief after stent placement with no procedure-related mortality. The majority of our patients with BTS who had airway stenting were
PITS and PTTS (64\%). We found symptomatic relief and $100 \%$ technical success in all cases. We preferred stenotic stents (SS) and we noticed that S-S were stable and efficacious if the narrowed part of SS was placed in the stenotic segment correctly.

The advantages of SS are that they are easily repositioned or removed, minimal granulation formation, and cost-effectivity. Disadvantages of SS if compared to other stent types are; stent high rates of migration, mucostasis, adherence of secretions due to the impairment of mucociliary clearance, and necessity 
Table 7. Characteristics of the study population affecting survival after interventional bronchoscopic procedures for benign diseases

\begin{tabular}{|c|c|c|c|c|c|c|}
\hline \multirow[b]{2}{*}{ Characteristics } & \multicolumn{4}{|c|}{ Survival } & \multicolumn{2}{|r|}{$\mathbf{p}$} \\
\hline & $\begin{array}{l}\text { Mean months } \\
(95 \% \mathrm{Cl})\end{array}$ & $\begin{array}{c}3 \text { months } \\
(\%)\end{array}$ & 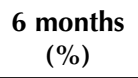 & $\begin{array}{c}12 \text { months } \\
(\%)\end{array}$ & Univariate & Multivariate \\
\hline Age, years & & & & & 0.001 & $0.02(0.08-0.5)$ \\
\hline$<58$ & $55(15-78)$ & 90 & 87 & 82 & & \\
\hline$\geq 58$ & $14(5-37)$ & 87 & 77 & 65 & & \\
\hline Type of underlying benign diseases & & & & & 0.06 & $0.37(0.1-1.1)$ \\
\hline PITS & $21(6-65)$ & 85 & 75 & 69 & & \\
\hline PTTS & $69(11-90)$ & 86 & 80 & 73 & & \\
\hline Anastomotic (PO/PT) & $40(14-74)$ & 88 & 80 & 80 & & \\
\hline TBM & $11(4-55)$ & 83 & 58 & 44 & & \\
\hline Degree of airway obstruction $(\%)^{\mathrm{a}}$ & & & & & 0.017 & $0.1(0.1-3.4)$ \\
\hline Grade $1(<50 \%)$ & $46(12-68)$ & 90 & 80 & 60 & & \\
\hline Grade 2 (50\%-74\%) & $24(8-87)$ & 88 & 81 & 72 & & \\
\hline Grade $3(75 \%-89 \%)$ & $15(8-36)$ & 84 & 75 & 72 & & \\
\hline Grade 4 (90\%-100\%) & $7(1-45)$ & 72 & 54 & 45 & & \\
\hline Type of lesion & & & & & 0.46 & \\
\hline Intrinsic obstruction & $36(7-79)$ & 89 & 83 & 70 & & \\
\hline Extrinsic obstruction & $14(5-56)$ & 87 & 69 & 52 & & \\
\hline Complex & $23(8-69)$ & 93 & 87 & 76 & & \\
\hline Comorbidities & $14(4-80)$ & 92 & 84 & 68 & 0.001 & $0.16(0.06-9.1)$ \\
\hline Diabetes mellitus & $14(5-73)$ & 92 & 88 & 78 & & \\
\hline Cardiovascular disease & $14(4-83)$ & 94 & 89 & 77 & & \\
\hline Cerebrovascular disease & $32(5-87)$ & 94 & 88 & 80 & & \\
\hline Chronic pulmonary disease & $14(4-55)$ & 92 & 85 & 75 & & \\
\hline Sytent type & & & & & 0.8 & \\
\hline Silicon stent & $26(7-72)$ & 94 & 89 & 82 & & \\
\hline Metallic stent & $23(15-39)$ & 50 & 50 & 50 & & \\
\hline Stent shape & & & & & 0.42 & \\
\hline Stenotic stent & $33(8-78)$ & 89 & 84 & 77 & & \\
\hline Y-shaped stent & $44(19-68)$ & 75 & 75 & 75 & & \\
\hline Straight stent & $14(5-55)$ & 86 & 79 & 71 & & \\
\hline Oki stent & $11(5-38)$ & 100 & 100 & 100 & & \\
\hline
\end{tabular}

PITS: Post-intubation tracheal stenosis, PTTS: Post-tracheostomy tracheal stenosis, TBM: Tracheobronchomalacia, ${ }^{a}$ Myer-Cotton stenosis grading system, PO: Post-anastomotic, PT: Post-transplantation.

of performing under general anesthesia with RB (19). Metallic stents (MS) advantages are easily delivery with $\mathrm{FB}$, well compatibility to the anatomic structure of the airway, low rates of migration and better mucociliary clearance. The disadvantages are it is permanent in the airways and can cause prominent granulation tissue within the stent (19). In our study, we used SS in the majority of our cases (88\%) because of these advantages. However, the usage of MS was very low, we think that depends on the characteristics of our patient population.

Despite many benefits, TBS are foreign bodies prone to complications. Complications may occur during follow-up; but life-threatening serious complications are rare (20). Hemorrhage, migration, airway perforation and pneumothorax are acute but rare complications. We observed minimal or moderate hemorrhage in ten patients; all hemorrhages were easily controlled. We encountered no complication-related deaths, but thirteen patients required non-invasive mechanical ventilation after the procedure. In addition that, acute complications rates were similar with the recent studies $(10 \%)$ than the previous studies with a ratio of $3-10 \%(21,22)$.

The reported rate of stent-related complications vary in the literature (mostly $40-60 \%$, and as high as 


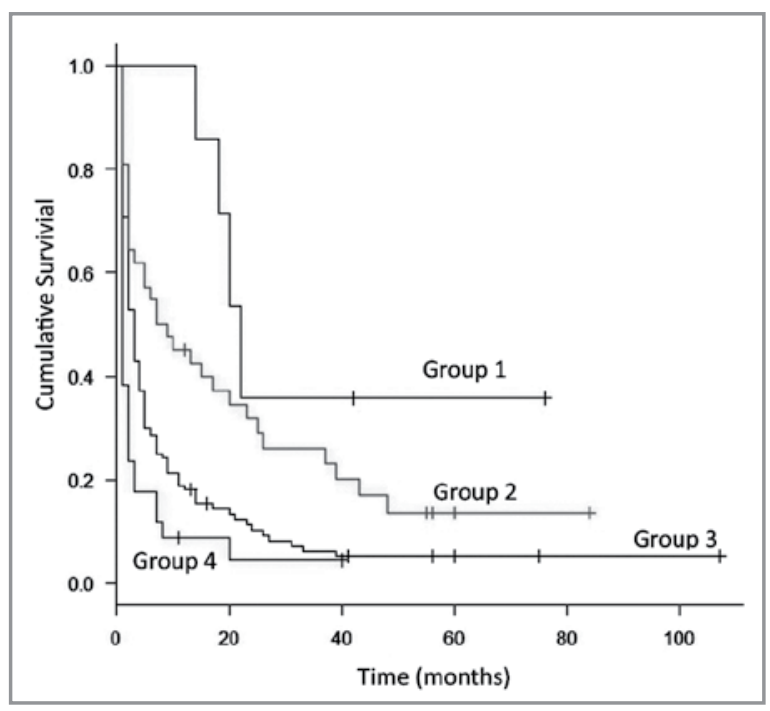

Figure 2. Factors significantly affecting survival in malign diseases using the Kaplan-Meier log-rank analysis (Group 1; patient with bronchial carcinoid, Group 2; patient with tumors metastatic to tracheobronchial tree, Group 3; patient with non-small cell lung cancer, Group 4; patient with small cell lung cancer, $\mathrm{p}<0.001$ by log-rank test).

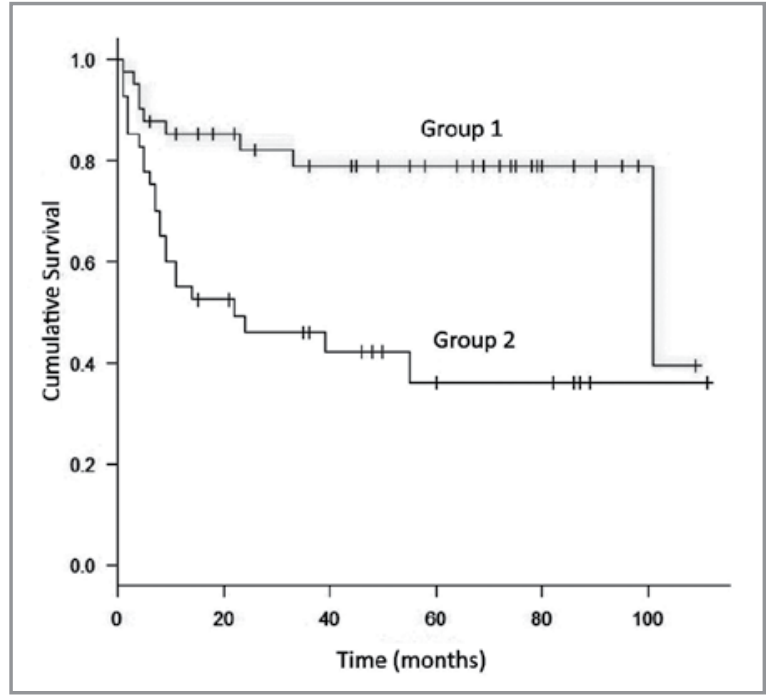

Figure 3. Factors significantly affecting survival in benign diseases using the Kaplan-Meier log-rank analysis (Group 1; patient age < 58 years, Group 2; patient age $\geq 58$ years, $\mathrm{p}<0.001$ by log-rank test).

$87 \%)$, based on the study population and the types/ material of airway stents deployed (23-26). Among long-term complications, granulation tissue formation with subsequent restenosis, stent occlusion or tumor growth obstruction, mucostasis, stent-migration, stent-fracture are described. Moreover, these compli- cations are more commonly seen with benign lesions than with malignant lesions $(27,28)$. The rates of longterm complications like granuloma formation and stent fractures are low due to the short life expectancy of patients with malignancy. The long-term complication rate in our study $(32 \%)$ is within this range. We observed a higher stenting complication rates in patients with BD $(43 \%)$ than patients with MD $(27 \%)$. In univariate analysis, benign airway stenosis, duration of follow-up and straight stent use were significant in the univariate analysis, whereas in the multivariate analysis only the follow-up period was significant.

Mucostasis is the most common stent complication (29). It is well known that stents impair mucus clearance, thus accumulation of secretions can be considered a slightly annoying problem or a severe complication. It consists of a coating of wires and polymers used for stents with biofilm. Secretions accumulate and block the stent lumen, causing severe shortness of breath in the patient. Halitosis develop due to bacterial and fungal colonization in the stent. The most common complication of our cases was mucostasis (19\%). Also, there was a relationship between mucostasis and the stent shape and benignity of disease.

Granuloma formation (GF) rates vary depending on the underlying disorder and the type of stent used. GF may be more common in patients with benign airway obstructions than in those from the malignant disease group $(30,31)$. This was probably due to the longer length of stent stay in the airways. In addition to that, the literature reports that GF is more common in MS than in SS (32). GF is the second most common complication in our cases (52 of 305 patients, 17\%) and similar in the previously reported range in the literature (2.9-15.2\%) and also in benign patients (26\%) GF is more common than malignant patients $(11 \%)(32-$ $34)$. In addition, similar to the literature (2.9-15\%), higher levels of GF were observed in MS (35\%) than SS $(15 \%)$ in our study. Likewise, we found an inverse correlation between the GF and the history of treatment (chemo and/or radiotherapy). This finding may suggest that chemo/radiotherapy contributes to the prevention of granulation development. The immunosuppressive effect of these therapies could have reduced the inflammatory response and as a consequence, the tissue granulation formation also.

Migration is another common complication associated with stents. SS have higher migration rates than 
MS. It is seen in $10 \%$ of malignant patients and twice as often in benign patients (35). In our study, there was a higher rate of migration in benign patients $(15 \%)$ than in malign patients $(6 \%)$. In addition, we found very low rates of migration in our cases with Y-stents $(2 \%)$, whereas the frequency of migration between type of stent was not significant. This can be attributed to the low (18\%) usage of MS.

In patients with both benign and malignant airway obstruction, airway stenting may provide immediate and durable palliation that can rescue the patient from imminent death and assure an improved quality of life $(36,37)$. In this study, we also investigated prognostic factors associated with overall survival after the airway stenting. In multivariate analysis, survival depends on the underlying malignancy type of patient with MD, and the age of the patients with $\mathrm{BD}$ (greater than 58 years). On the other hand, the site of the lesion, degree of airway obstruction, type of lesion, treatment modality, presence of comorbidities, type and shape of stents were not significantly associated with increased mortality in our study.

In conclusion; our study showed that all the patients had symptomatic relief after airway stenting. No stent-related-deaths were recorded in our population due to stent placement and permanence in the airways. The results of this study and the systematic review suggest that airway stenting is a safe and effective treatment option in the management of benign and malignant airway disorders.

\section{CONFLICT of INTEREST}

The authors reported no conflict of interest related to this article.

\section{AUTHORSHIP CONTRIBUTIONS}

Concept/Design: MAÖ, ECS

Analysis/Interpretation: ECS, EÇ

Data Acquisition: DT, EGUC

Written by: ECS, GÖ

Critical Revision: DD, EGUC, MAÖ

Final Approval: All of authors.

\section{REFERENCES}

1. Ost DE, Ernst A, Grosu HB, Lei X, Diaz-Mendoza J, Slade $M$, et al. Therapeutic bronchoscopy for malignant central airway obstruction: success rates and impact on dyspnea and quality of life. Chest 2015;147(5):1282-98.
2. Kvale PA, Simoff A, Prakash UBS. Palliative care. Chest 2003;123(90010):284-311.

3. Saad CP, Murthy S, Krizmanich G, Mehta AC. Self expandable metallic airway stents and flexible bronchoscopy: long-term outcomes analysis. Chest 2003;124(5):1993-9.

4. Mehta AC, Dasgupta A. Airway stents. Clin Chest Med 1999;20:139-51.

5. Razi SS, Lebovics RS, Schwartz G, Sancheti M, Belsley S, Connery $C P$, et al. Timely airway stenting improves survival in patients with malignant central airway obstruction. Ann Thorac Surg 2010;90:1088-93.

6. Chung FT, Chen HC, Chou CL, Yu CT, Kuo CH, Kuo HP, et al. An outcome analysis of self-expandable metallic stents in central airway obstruction: a cohort study. J Cardiothorac Surg 2011;6:46.

7. Dooms C, De Keukeleire T, Janssens A, Carron $K$ Performance of fully covered self-expanding metallic stents in benign airway strictures. Respiration 2009;77:4206.

8. Gildea TR, Murthy SC, Mason DP, Mehta AC. Performance of a self-expanding silicone stent in palliation of benign airway conditions. Chest 2006;130:1419-23.

9. Hoag JB, Sherman M, Lund ME. Practice patterns for maintaining airway stents deployed for malignant central airway obstruction. I Bronchology Interv Pulmonol 2010;17:131-5.

10. Dumon JF. A dedicated tracheobronchial stent. Chest 1990;97:328-32.

11. Freitag L. Airway stents. Eur Respir Mon 2010;48:190-217.

12. Colt HG, Harrell JH. Therapeutic rigid bronchoscopy allows level of care changes in patients with acute respiratory failure from central airways obstruction. Chest 1997; 112:202-6.

13. Stöhr S, Bolliger CT. Stents in the management of malignant airway obstruction. Monaldi Arch Chest Dis 1999;54:264-8.

14. Galluccio G, Lucantoni G, Battistoni P, Paone G, Batzella $S$, Lucifora $V$, et al. Interventional endoscopy in the management of benign tracheal stenoses: definitive treatment at long-term follow-up. Eur I Cardiothorac Surg 2009;35:429-33.

15. Shitrit D, Kuchuk M, Zismanov V, Rahman NA, Amital A, Kramer MR. Bronchoscopic balloon dilatation of tracheobronchial stenosis: long-term follow-up. Eur J Cardiothorac Surg 2010;38(2):198-202.

16. Bolliger CT, Sutedja TG, Strausz J, Freitag L. Therapeutic bronchoscopy with immediate effect: laser, electrocautery, argon plasma coagulation and stents. Eur Respir J 2006;27:1258-71.

17. Zhou GW, Huang HD, Sun QY, Xiong Y, Li Q, Dong YC. Temporary placement of a metallic stent could lead to long-term benefits for benign tracheobronchial stenosis. J Thorac Dis 2015;7:398-404. 
18. Charokopos N, Foroulis CN, Rouska E, Sileli MN, Papadopoulos N, Papakonstantinou C. The management of postintubation tracheal stenoses with self-expandable stents: early and longterm results in 11 cases. Eur J Cardiothorac Surg 2011;40:919-24.

19. Rodriguez AN, Diaz-Jimenez JP, Edell ES. Silicone stents versus metal stents for the management of benign tracheobronchial disease: Con: Metal stents. J Bronchol 2000;7:184-7.

20. Guibert N, Mazieres J, Lepage B, Plat G, Didier A, Hermant $C$. Prognostic factors associated with interventional bronchoscopy in lung cancer. Ann Thorac Surg 2014;97(1):253-9.

21. Ost DE, Ernst A, Grosu HB, Lei X, Diaz-Mendoza J, Slade $M$, et al. Complications following therapeutic bronchoscopy for malignant central airway obstruction: results of the AQuIRE registry. Chest 2015;148(2):450-71.

22. Jeon K, Kim H, Yu CM, Koh WJ, Suh GY, Chung MP, et al. Rigid bronchoscopic intervention in patients with respiratory failure caused by malignant central airway obstruction. J Thorac Oncol 2006;1(4):319-23.

23. Dooms $C$, De Keukeleire $T$, Janssens $A$, Carron $K$. Performance of fully covered self-expanding metallic stents in benign airway strictures. Respiration 2009; 77:4206

24. Gildea TR, Murthy SC, Sahoo D, Mason DP, Mehta AC. Performance of a self-expanding silicone stent in palliation of benign airway conditions. Chest 2006;130:1419-23.

25. Madden BP, Loke TK, Sheth AC. Do expandable metallic airway stents have a role in the management of patients with benign tracheobronchial disease? Ann Thorac Surg 2006;82:274-8.

26. Eller RL, Livingston WJ, Morgan CE, Peters GE, Sillers MJ, Magnuson JS, et al. Expandable tracheal stenting for benign disease: worth the complications? Ann Otol Rhinol Laryngol 2006; 115:247-52.

27. Dumon JF, Cavaliere S, Diaz-Jimenez JP, Vergnon JM, Venuta F, Dumon MC. Seven experience with the Dumon prosthesis. J Bronchol 1996;31:6-10.
28. Noppen M, Meysman M, Claes I, D'Haese J, Vincken W. Screw-thread vs. Dumon endoprosthesis in the management of tracheal stenosis. Chest 1999;115:532-5.

29. Zakaluzny SA, Lane JD, Mair EA. Complications of tracheobronchial airway stents. Otolaryngol Head Neck Surg 2003;128:478.

30. Chung FT, Lin SM, Chen HC, Chou CL, Yu CT, Liu CY, et al. Factors leading to tracheobronchial self expandable metallic stent fracture. J Thorac Cardiovasc Surg 2008;136:132835.

31. Chung FT, Lin SM, Chou CL, Chen HC, Liu CY, Yu CT, et al. Factors leading to obstructive granulation tissue formation after ultra flex stenting in benign tracheal narrowing. Thorac Cardiovasc Surg 2010;58:102-7.

32. Saad CP, Murthy S, Krizmanich G, Mehta AC. Selfexpandable metallic airway stents and flexible bronchoscopy: long-term outcomes analysis. Chest 2003;124:19939.

33. Murgu S, Langer S, Colt H. Bronchoscopic intervention obviates the need for continued mechanical ventilation in patients with airway obstruction and respiratory failure from inoperable non-small-cell lung cancer. Respiration 2012;84(1):55-61.

34. McGrath EE, Warriner D, Anderson P. The insertion of selfexpanding metal stents with flexible bronchoscopy under sedation for malignant tracheobronchial stenosis: a single center retrospective analysis. Arch Bronchopneumol 2011;48:43-8

35. Ryu YJ, Kim H, Yu CM, Choi JC, Kwon YS, Kim J, et al. Comparison of natural and Dumon airway stents fort he management of benign tracheobronchial stenoses. Respirology 2006; 11:748-54.

36. Stephens KE Jr, Wood DE. Bronchoscopic management of central airway obstruction. I Thorac Cardiovasc Surg 2000;119:289-96.

37. Mathisen DJ, Grillo HC. Endoscopic relief of malignant airway obstruction. Ann Thorac Surg 1989;48:469-75. 